\title{
WOMEN AND DERADICALISM: UNDERSTANDING THE WOMEN'S ROLE IN DEVELOPING PEACEFUL CULTURE
}

\author{
Wanda Fitri \\ Fakutlas Dakwan dan Ilmu Komunikasi, UIN Imam Bonjol,wandafitri@uinib.ac.id
}

\author{
\begin{tabular}{l|l|l} 
Diterima: 24 Februari 2019 & Direvisi : 5 Mei 2019 & Diterbitkan: 30 Juni 2019
\end{tabular}
}

\begin{abstract}
The development of scholars, sects in Islam thought is being proof of the development of Muslims as demanded to be respectful of the differences from the beginning. In Indonesia, since the formation of the NKRI, the most important sacrifice made by the founders (Muslims) is concerned with unity. The unity in togetherness, kinship, and respect for diversity, not group individualism, intellectualism, materialism makes Islam as the state ideology even though most of the people are Muslims. As the largest Muslim majority in the world, Indonesia is inseparable from the threat of radicalism and terrorism. The multiethnic and religious social life of Indonesia are being triggers prejudice among the religious groups. Intolerant attitude in responding to the differences is often shown by different groups which tends to trigger radicalism that leads to violence in the form of acts of terror in the name of religion (Islam). Unfortunately, in various acts of radicalism, women are the victims. The problem is whether women only become passive victims, even though women have strategic roles in eroding and suppressing radicalism. Various studies have proven bow women play a large role in the process of building diversity and a culture of peace. This paper expected to see women as survivors, peace activists / activists, and peace agents whose actions cannot be ignored both psychologically and socially.
\end{abstract}

Keywords: Womans, Deradicalism, Religious Radicalism, Peace Cultural.

\begin{abstract}
Abstrak
Berkembangnya ratusan aliran, sekte, dan mazhab pemikiran dalam Islam cukup menjadi bukti bagaimana kaum muslimin sejak di awal perkembangannya telah dituntut bersikap saling menghargai perbedaan.Di Indonesia sendiri sejak dibentuknyaNegara Kesatuan Republik Indonesia (NKRI) pengorbanan terpenting yang dilakukan oleh para pendiri bangsa ini (Muslim) adalah mementingkan persatuan. Persatuan dalam kebersamaan, kekeluargaan, dan menghormati keberagaman bukan individualisme kelompok, intelektualisme, materialisme, atau menjadikan Islam sebagai ideologi negara meski rakyatnya mayoritas adalah muslim.Sebagai negara mayoritas Muslim terbesar di dunia, Indonesia tidak lepas dari ancaman radikalisme dan terorisme. Kehidupan sosial Indonesia yang multietnis dan agamalah yang memicu terjadinya prasangka antar kelompok beragama. Sikap intoleran dalam menyikapi perbedaan sering ditunjukan oleh kelompok-kelompok yang berbeda cenderung memicu terjadinya perilaku radikalisme yang berujung pada kekerasan dalam bentuk aksi teror yang mengatasnamakan agama (Islam). Sayangnya, dalam berbagai aksi radikalisme, perempuanlah yang menjadi korban. Permasalahnnya adalah apakah perempuan hanya menjadi korban pasif, padahal perempuan memiliki peran-peran strategis dalam mengikis dan meredam radikalisme. Berbagai penelitian telah membuktikan bagaimana kaum perempuan memeiliki peran yang besar di dalam proses membangun keragaman dan budaya perdamaian. Tulisan ini ingin melihat perempuansebagai surivor, pejuang/aktivis perdamaian, dan agen perdamaian yang kiprahnya tidak dapat diabaikan baik secara psikologis maupun sosial.
\end{abstract}

Kata Kunci: Perempuan, Deradikalisme, Radikalisme Agama, Budaya Damai. 


\section{Latar Belakang}

Radikalisme yang berbasis agama biasanya cenderung mengarah pada politik identitas untuk menyatakan pemikiran mereka sebagai yang paling benar. Mereka cenderung intoleran terhadap perbedaan. Sikap intoleransi tersebut melahirkan perilaku radikal atas nama agama (Islam) yang dipicu oleh berbagai hal seperti ketidakadilan, ketimpangan sosial, korupsi, tidak tegasnya institusi pemerintah lemahnya supremasi hukum, dan sebagaimya. Dalam berbagai kasus radikalisme di dunia aksi-aksi kekerasan dan terorisme sering terjadi. Bahkan Indonesia sebagai negara mayoritas Muslim terbesar di dunia juga tidak lepas dari ancaman radikalisme dan terorisme. Serangan bom di kawasan Thamrin pada awal tahun 2016 dan di Kampung Melayu pada awal tahun 2017 yang terkait dengan ISIS menjadi salah satu contoh nyata. Berbagai penelitian menunjukan ajaran-ajaran radikalisme dan terorisme sudah masuk ke institusi pendidikan dan menyebar melalui media sosial. Sementara perempuan seringkali menjadi sasaran dakwah ajaran radikalisme baik sebagai pelaku yang terlibat aksi radikalisme maupun korban dari aksi terorisme atas nama agama.

Penelitian yang dilakukan oleh Wahid Foundation tahun 2016 tentang intoleransi menunjukan gambaran yang memprihatikan. Dari keseluruhan responden 59,9\% diantaranya memiliki kelompok yang tidak disukai (LGBT, Yahudi, Kristen, Shiah, Wahabi, Budha, dan China). 92,2\% dari kelompok yang dibenci tersebut masuk ke dalam pemerintahan dan $82,4 \%$ tidak mau hidup berdampingan dengan kelompok tersebut. Dalam kurun waktu 20092016, hasil kompilasi KOMNAS Perempuan menemukan sejumlah 421 peraturan daerah (Perda) diskriminatif terhadap minoritas (agama) dan perempuan. Perempuan dapat menjadi aktor penting dibalik radikalisme, apakah sebagai korban yang disebabkan oleh situasi yang menjerat mereka atau sebagai korban yang dikorbankan (indoktrinasi dari suami yang terlibat dalam radikalisme).

Perempuan sangat rentan dikesploitasi sehingga mudah terlibat dalam radikalisme, sebagaimana banyak terjadi di beberapa negara seperti Pakistan,Nigeria, bahkan Indonesia. Menurut penelitian dari Institute for Policy Analysis of Conflict pelaku radikalisme di Indonesia terutama perempuan mendapatkan pengetahuan dan pemahaman internet atau media sosial. Keterbukaan informasi dan peluang mengembangkan diri lebih luas yag didapat perempuan membawa mereka pada keinginan ikut aktif berperan. Sebaliknya, dalam situasi konflik maupun perdamaian, kelompok perempuan selalu terabaikan (diabaikan). Perempuan seringkali dimarginalkan baik oleh sistem maupun dalam perlakuan pengambilan kebijakan. Padahal peran perempuan penting dalam menangkal radikalisme, karena sesungguhnya perempuan bisa berperan sebagai penyebar perdamaian di lingkungan sekitar tempat tinggal mereka. Perempuan bisa memulai membangun perdamaian dari dalam keluarganya sendiri. Perempuan memiliki keunggulan kompetitif dan komparatif sehingga ia memiliki banyak ruang dan kesempatan yang lebih luas dalam memberikan pengaruh terhadap lingkungan sosialnya. Namun pada kenyataannya, keterlibatan perempuan sebagai agen perdamaian dan resolusi konflik masih rendah dan sangat terbatas, misal pada konflik Aceh beberapa tahun yang lalu.

Menurut laporan dan pegamatan dari beberapa lembaga swadaya masyarakat (NGO) menjelaskan bagaimana minimnya keterlibatan perempuan dalam penyelesaian konflik karena menurut pandangan masyarakat pada umumnya, permasalahan politik dan kemasyarakatan yang berhubungan dengan pembuatan kebijakan bukanlah urusan 
perempuan ${ }^{1}$. Padahal ketika berada di dalam situasi genting seperti konflik atau bencana, perempuan memikul tanggungjawab yang sangat luas (berat). Mereka bertanggungjawab terhadap keselamatan dan keberlangsungan hidup anak-anak mereka, merawat orangtua, menyediakan makanan, dan obat-obatan ${ }^{2}$. Sementara laki-laki biasanya akan pergi keluar rumah untuk mencari bantuan atau ikut berperang. Selanjutnya, pasca konflik biasanya jasa-jasa perempuan di atas akan terabaikan karena sudah dianggap sebagai bentuk "tanggungjawab yang seharusnya". Jadi perlakuan itupun tidak pernah dihargai atau dinilai sebagai prestasi. Berbeda dengan lakilaki yang pergi berjuang ke medan perang, biasanya mereka akan dianggap sebagai pejuang.

Dalam berbagai konflik, perempuan seringkali menjadi korban atau yang dirugikan oleh situasi tersebut. Mereka tidak hanya sekedar menjadi korban situasi tetapi juga seringkali mendapatkan perlakuan kekerasan, mulai dari kekerasan fisik, psikologis, seksual, hingga kekerasan sosial/politik. Permasalahannya adalah apakah dalam setiap konflik komunal yang terjadi perempuan selalu menjadi korban atau disposisikan sebagai korban? Apakah perempuan tidak memiliki peran strategis yang dapat dimainkan, padahal selama ini peran-peran strategis tersebut sudah mereka tunjukan (kasus konflik di Ambon, Poso, Aceh, Kalimantan Barati, dan seterusmya) hanya saja mungkin kurang diapresiasi ${ }^{3}$.Sementara, keberadaan kelompok

${ }^{1}$ Sri Lestari Wahyuningrum. Perempuan dan Perdamaian di Aceh, (dalam Women for Peace 2007) .

${ }^{2}$ Wanda Fitri. Pengaruh Nilai Budaya Sapikua, Dukungan Sosial, dan Trait Kepribadian Terhadap Resiliensi Orang Minang, (Bandung: Universitas Padjadjaran. Disertasi Tidak diterbitkan 2015).

${ }^{3}$ Kholifah, D.Rubiayanti. Peran Perempuan di Dalam Membangun Perdamaian Harus Diapresiasi. Jurnal Swara Rahima No. 35 Th XI Juli 2011. jaringan perempuan juga semakin banyak dan menguat. Hal ini memberikan harapan kepada perempuan untuk dapat tampil percaya diri dalam keikutsertaan mereka membangun perdamaian dan diapresisi. Disamping itu kebaradaan tokoh/pemuka agama (terutama perempuan) diharapkan dapat membantu merekonstruksi penafsiran agama (Islam) secara baik dalam rangka menangkal radikalisme.

\section{Posisi Agama (Islam) Dalam Tantangan Perdamaian}

Islam adalah agama perdamaian, pernyataan ini membantah pendapat para orientalis yang menyebutkan Islam adalah agama jihad (suka berperang). Islam menekankan persamaan derajat/status, menunjung tinggi rasa persaudaraan tanpa membedakan suku, agama, dan ras (QS. Al Hujurat: 49). Sejak di awal perkembangannya pada masa Nabi Muhammad saw, Islam sudah membuktikan bagaimana membangun perdamaian yang dikenal sebagai Piagam Madinah. Meski pada akhirnya asi-aksi kekerasan yang menggunakan Islam berkembang bahkan seolah-olah dijustifikasi oleh Islam. Hal itu dimungkinkan karena dipengaruhi oleh faktor pemikiran dan pemahaman yang sempit serta latar belakang sosio-historis atau politik yang kurang dipahami atau keliru.

Dalam masyarakat majemuk seperti Indonesia, agama seperti dua sisi mata uang yang berbeda. Di satu sisi agama adalah faktor pemersatu (integrasi) dan sisi yang lain, ia adalah pembeda (disintegrasi). Dalam beberapa kasus terbukti bagaimana agama dapat dijadikan sebagai alat pemecah belah atau sumber konflik. Dalam banyak kajian kerukunan antar umat beragama menunjukan bahwa penyebab konflik agama bukan bersumber dari agama itu sendiri melainkan karena pemikiran dan pemahaman yang sempit dari penganutnya. Oleh karenanya yang perlu 
diperbaiki adalah cara pikir, pemahaman, atau penafsiran ulang terhadap ajaran-ajaran agama yang benar dari penganutnya (termasuk Islam).

Perilaku radikal berawal dari para penganut agama yang menilai bahwa pemahaman merekalah yang paling benar. Jika ada kelompok yang berbeda pendapat dengan mereka dianggap menyimpang atau sesat bahkan dengan mudah dikafirkan. Padahal perbedaan adalah bagian dari sunatullab (QS. Al Hujurat:13). Sentimen agama seringkali dapat dijadikan sebagai alat untuk mendapatkan dukungan (melipatgandakan dukungan) terhadap pandangan yang dianggap benar oleh suatu kelompok. Contoh, kasus aksi damai pembelaan agama (Islam) di awal tahun 2017 yang dikomandoi oleh ormas Front Pembela Islam (FPI). Meski secara umum, kasus tersebut seperti kasus bersama umat Islam tetapi jika ditilik dengan seksama terlihat bahwa sebenarnya pada kenyataannya agama tidaklah hadir sebagai entitas tunggal (agama yang murni) melainkan dalam bentuk kelompokkelompok sesuai aliran-aliran pemikiran yang dianut. Hal itu menyebabkan munculnya kelompok-kelompok radikalisme. Masingmasing kelompok ingin menunjukan eksistensi mereka sebagai kelompok yang paling benar dan shabih, (misalnyaFront Pembela Islam, Hizbur Tahrir Indonesia, dst). Mereka ingin menghadirkan diri sebagai repesentatif yang setara dengan kelompok mainstreamseperti Nahdatul Ulama an Muhammadiyah.

$$
\text { Islam adalah agama }
$$

perdamaian. Islam asal katanya adalah salam atau Al fil al Islam yang artinya damai. Dalam Alquran dianjurkan kepada setiap orang Islam (orang-orang yang beriman) untuk menyebarkan salam sebagai bentuk rasa sukacita dan kedamaian. Ucapan salam diartikan sebagai bentuk penghargaan terhadap sesama manusia. Seorang Islam adalah yang memberikan rasa damai dan ketenangan kepada orang lain dari ganguan ucapan dan tindakannya. Perdamaian berarti hidup dalam situasi yang menyenangkan dan saling menghormati tanpa membedakan etnis, suku, budaya, ststus sosial, maupun agama. Sebagaimana firman Allah swt dalam AlQur'an surat Al Isra ayat 70:

Kami menghormati anak. Adam dan kami bawa mereka di darat dan di laut. Kami beri mereka rezeki dari hasil bumi yang baikbaik. Kami unggulkan mereka dari yang lain.

Ayat di atas menjelaskan bagaimana Allah menyebut manusia dengan sebutan bani Adam bukan $\mathrm{Al}$ Muslimun maupun $\mathrm{Al}$ Mukminin ini berarti bahwa Allah penghormatan diberikan kepada semua manusia tanpa membedakan sedikitpun, karena semua manusia adalah hambaNya, tinggal manusianya saja apakah ia akan menyembah Allah atau bukan. Dalam firmanNya Allah juga menyebutkan bahwa hanya Allah yang Maha Tahu dan berkehendak siapa yang akan diberinya petunjuk. Dengan kata lain, masalah perbedaan agama/keyakinan bukan urusan manusia. Jadi tidak ada alasan bagi setiap orang Islam untuk berperang atau memusuhi umat beragama lainnya kecuali yang diizinkan Allah sesuai perintah-Nya.

\section{Keterlibatan Perempuan Dalam Gerakan Radikalisme}

Bukan tren baru lagi menjadikan perempuan sebagai pelaku aksi terorisme. Di Pakistan, perempuan menjadi sasaran dakwah kelompok radikalisme. Mereka dinikahi, diintimidasi, dan diinfiltrasi dengan pahampaham radikalisme oleh maulananya (Imam) yang seharusnya menjadi tempat bertanya mereka di tengah situasi politik negara yang tidak stabil (Bushra Qadeem, 2017). Sementara di Nigeria, menurut Rafatul Abdulhamid (2017) kelompok radikal militan Boko Haram menjadikan perempuan-perempuan muda yang diculiknya sebagai sasaran penyebaran paham radikal mereka. Para perempuan tersebut dimanfaatkan untuk mengumpulkan informasi serta merekrut mereka dengan paksa untuk 
mempromosikan ideologi radikal mereka. Ketika sebagian perempuan yang ditangkap tersebut dipaksa menjadi anggota kelompok militan mereka dilepaskan atau berhasil melepaskan diri, keluarga mereka tidak semerta-merta menerima begitu saja karena dianggap telah tercemar sehingga berbahaya dan menjadi musuh.

Di Indonesia, menurut penelitian Nuraniyah (2017) dari Institute for Policy Analysis of Conlict menggambarkan bagaimana di Poso Sulawesi Tengah, perempuan pada kelompok radikal ikut memegang senjata, dan tidak kurang pula yang ingin pergi ke daerah konflik Bahkan kasus terbaru yang menyentak dunia adalah tertangkapnya seorang perempuan benrnama Dian Yulia Novi, isteri Bahrun Naim pelaku bom Sarinah (2016) yang berencana ingin melakukan bom bunuh diri di istana negara pada 11 Desember 2016 lalu (Kompas.com). Tragedi tersebut menyibak fakta keterlibatan sejumlah perempuan Muslim dalam gerakan radikalisme dan terorisme baik di dunia maupun di Indonesia.

Namun di dalam situasi dan kondisi tersebut di atas pertanyaan yang mungkin membingungkan adalah apakah perempuan dalam posisi tersebut dapat disebut sebagai korban? Menurut Bushra Qadim Hyder (2017), perempuan pelaku radikalisme adalah korban, mereka dieksploitasi atas nama agama, lalu disuruh berperang oleh kelompok radikal. Begitu juga yang terjadi di Nigeria, menurut Rafatu Abdulhamid (2017), perempuanperempuan tersebut diculik dengan paksa, mereka mendapatkan kekerasan. Boko Haram merekrut perempuan-perempuan yang tidak puas terhadap keadilan, ketidaksetaraan, dan kterasingan menjadi anggota kelompok militan mereka yang kemudian melakukan intimidasi dan pencucian otak terhadap perempuanperempuan muda yang mereka culik dan kemudian dipkasa menjadi anggota atau simpatisan. Sedangkan kasus di Indonesia, menurut Ani Rufaida dari Research Center for Policy Study and Terorism Universitas Indonesia (2017), perempuan-perempuan yang terlibat dalam radikalisme biasanya dipengaruhi oleh suami mereka. Bahkan tak jarang mereka terjebak karena sebelumnya tidak mengetahui latarbelakang/pekerjaan calon suami yang dikenal melalui teman atau media sosial. Mereka tidak tahu kalau suami mereka terhubung dengan kelompok radikalisme.

\section{Peran Perempuan Dan Radikalisme}

Melihat pada banyak kasus kekerasan atas nama agama tiak dapat diingkari bahwa perempuan tetap menjadi menjadi korban. Apakah mereka sebagai pelaku radikalisme atau aksi kekerasan seperti teroris atau penyebaran dari paham radikalisme itu sendiri. Sebagai pelaku aksi teror atau radikalisme, perempuan adalah kelompok korban yang dikorbankan. Mereka bisa saja terjebak dalam situasi atau memang simpatisan dari paham radikalisme tersebut. Perempuan adalah korban yang dipaksa (terpaksa) menjadi bagian dari pelaku radikal tersebut. Bahkan di dalam situasi yang keterlibatannya tidak secara langsung sebagai istri dari pelaku aksi radikalisme (teroris) perempuan tetap saja menjadi korban, karena para lelaki mereka yang ikut jaringan teroris ikut pergi "berjihad" meningglkan keluarga. Makanya, perempuan disebut sebagai korban yang mengalami korban ganda dari konflik komunal yang dihadapinya. Di satu sisi mereka menjadi sasaran dari kekerasan tersebut karena harus menanggung dampak dari situasi yang ada.

Di sisi lain, mereka harus bertahan sebagai pelindung dan penjaga yang bertanggungjawab terhadap keberlangsungan hidup anak-anak dan diri mereka.Mereka berjuang sendirimenemukan solusi dari permasalahan atau kesulitan yang sedang dihadapi. Mereka berusaha keras mengatasi semua tekanan dan himpitan dari kedaan yang tidak menyenangkan (adversitas). Dalam 
beberapa penelitian untuk kondisi seperti itu biasanya perempuan, terbukti perempuan memiliki resiliensi (daya lentur) yang lebih baik dari laki-laki ${ }^{4}$

Mengapa perempuan? Mengapa perempuan yang harus memainkan peran paling aktif dalam menangkal radikalisme? Dalam teori feminis dijelaskan bahwa perempuan adalah kelompok yang paling diandalkan dalam soal kesetiaan dan kepatuhan. Kelompok yang paling dipercaya dan aling bersahabat dengan agama, meski pelaku agama seringkali tidak ramah pada mereka. Perempuan adalah benteng yang paling utama dalam melindungi anak-anak dan keluarga ketika terjadi hal-hal yang tidak diinginkan. Oleh karena itu, perempuan adalah salah satu elemen yang sangat penting dan memiliki peran strategis dalam menangkal paham radikalisme dan menanamkan budaya damai. Perempuan memiliki kemampuan dan keluwesan dalam menyebarkan gerakan moral yang mengempanyekan wajah agama yang damai, humanis, inklusif, dan pluralis.

Gerakan perempuan melalui transformasi kultural dan pemberdayaan berperspektif keadilan dan kesetaraan gender akan berhadil mempropagandakan anti radikalisme. Perempuan dapat berperan proaktif dalam menangkal radikalisme melalui pendidikan dalam keluarga dengan menanamkan sejak dini budaya damai, sikap toleransi, dan humanis. Khusus dalam Islam, sebagai ibu perempuan dapat melakukan reinterpretasi terhadap teksteks AlQur'an dan Hadist yang berpotensi melahirkan aksi kekerasan dan radikalisme dan mengajarkan kepada anak-anaknya. Mereka juga dapat menanamkan nilai-nilai kebersamaan dan pluralis dengan

4 Fitri, Wanda. Pengaruh Nilai Budaya Sapikua, Dukungan Sosial, dan Trait Kepribadian Terhadap Resiliensi Orang Minang, Bandung: Universitas Padjadjaran. Disertasi (Tidak diterbitkan) 2015.

mensosialisasikan perilaku toleran di dalam keluarga dan lingkungan sosial tempat tinggal.

Beberapa hal yang menjelaskan bagaimana perempuan lebih luwes dalam menemukan pemecahan dari masalah yang dihadapinya sebagai berikut:

1. Resolusi kognitif, yaitu saat berada dalam situasi koflik yang harus dipahami sebagai kenyataan hidup dan kondisi yang abnormal, maka perempuan tetap melakukan kegiatan konkrit yang berorientasi pada keberlangsungan hidup anggota keluarga mereka.

2. Resolusi emosional, biasanya diawali dengan sikap kesedihan akibat kehilangan setelah itu mereka akan segera menunjukan sikap menerima terhadap kenyataan yang terjadi. Kemudian muncul sikap memaafkan keadaan, dan setelah itu membawanya berpikir rasional bahwa ada kehidupan ke depan yang lebih penting untuk dipertahankan.

Resolusi perilaku pada tahap ini terjadi perbaikan perilaku dimana mereka bersedia berkomunikasi dan mendukung semua program rekonstruksi untuk terlaksana dengan cepat dan baik. Perempuan pada umumnya sangat peka dengan situasi dan yang akan terjadi berikutnya. Oleh karena itu mereka sering memulai inisiatif dan aktif dalam melakukan perbaikan keadaan.

\section{Kesimpulan}

Perempuan memiliki peluang dan kesempatan yang lebih luas dalam menangkal paham radikalisme melalui sikap dan pengajaran deradikalisme. Perempuan dinilai cakap dalam menanamkan nilai budaya damai dan sikap toleran yang baik melalui perannya sebagi ibu dan istri. Melalui pengasuhan dan pendidikan di dalam keluarga, perempuan dapat dengan bebas dan berperan aktif dalam membentuk kepribadian dan pola pikir anakanak mereka. Oleh karena itu, diperlukan apresiasi masyarakat terhadap perempuan 
dalam membangun perdamaian, karena masih banyak masyarakat yang mengabaikan keterlibatan perempuan dalam mengantisipisasi perkembangan pemahaman radikalisme di tengah masyarakat. Bahkan sebaliknya, masyarakat masih cenderung berpendapat atau melihat perempuan sebatas sebagai korban dan hampir tidak diikutsertakan dalam pemecahan masalah/konflik. Akibatnya perempuan terposisikan sebagai korban yang kembali dikorbankan.

Menurut beberapa kajian, hal itu dimungkinkan karena pengungkapan perempuan tentang konflik komunal di ruang publik cenderung simbolik. Mereka terabaikan di tengah isu-isu besar lainnya seperti korupsi dan terorisme. Padahal dalam banyak kasus menunjukan bagaimana perempuan berperan aktif dalam membangun perdamaian melalui pengalamannya sebagai korban dan pengembangan nilai-nilai budaya damai yang di dapatnya dari pengalaman tersebut. Peran perempuan dalam menangkal radikalisme sangat penting dan strategis yaitu sebagai penyebar perdamaian di dalam keluarga dan di lingkungan sekitarnya. Perempuan dapat menciptakan kondisi damai di dalam keluarga melalui budaya damai yang ditanamkan di pada anak-anak mereka. sementara di luar rumah, perempuan memiliki kesempatan yang sama melalui organisasi masyarakat maupun aktivitas sosial yang mereka ikuti.

\section{Daftar Kepustakaan}

Abbas, Nasir, Memberdayakan Potensial Masyarakat dalam Pemberantasan Terorisme, Makalah disampoaikan dalam Seminar Nasional Menuju Kerangka Hukum Pemberantasan Terorisme yang Komprehensif, kerjasama Lazuardi Birru dan BNPT, Jakarta, 23 Juni 2011 (Tidak diterbitkan).

Abdul Hamid, Rafatu, Boko Haram, Islamism, Politics, and Women's Security in Nigeria, Makalah yang disampaikan dalam The
International Seminar on Women Ulama, Cirebon, 25 April 2017 (Tidak diteribitkan).

Azizy, A. Qodri A, (2003). Pendidikan [Agama] untuk Membangun Etika Sosial, Semarang: Aneka Ilmu.

Azra, Azyumardi, Akar Radikalisme Keagamaan: Peran Aparat Negara, Pemimpin Agama dan Guru untuk Kerukunan Umat Beragama, Makalah disampaikan dalam diskusi "Memperkuat Toleransi Melalui Sekolah," The Habibie Center, Hotel Aston, Bogor, 14 Mei 2011 (Tidak diterbitkan).

Azra, Azyumardi, (1996). Pergolakan Politik Islam, dari Fundamentalis, Modernisme bingga Post-Modernisme, Jakarta: Paramadina.

Bubalo, Anthony dan Greg Fealy, (2007). Jejak Kafilah: Pengaruh Radikalisme Timur Tengah di Indonesia, terj. Akh. Muzakki, Bandung: Mizan

Davis, Michael, "Laskar Jihad and the Political Position of Conservative Islam in Indonesia," dalam Journal of Contemporary Southeast Asia, Vol. 24, 2002.

Fealy, Greg and Virginia Hooker (ed.). (2006). Voices of Islam in Southeast Asia: A Contemporary Sourcebook, Singapore: ISEAS.

Fitri, Wanda (2015). Pengaruh Nilai Budaya Sapikua, Dukungan Sosial, dan Trait Kepribadian Terhadap Resiliensi Orang Minang, Bandung: Universitas Padjadjaran. Disertasi (Tidak diterbitkan).

Hyder, Bushran, (2017). Working at The Communities Challenging Religious Extremism. Makalah diseminarkan The International Seminar on Women Ulama, Cirebon, 25 April 2017.

Hendropriyono, AM, (2009). Terorisme Fundamentalisme Kristen, Yahudi, Islam, Jakarta: Kompas.

Ismail, Noor Huda. (2010). Temanku Teroris, Bandung: Mizan Publikasi 
Kholifah, D.Rubiayanti. (2011). Peran

Perempuan di Dalam Membangun

Perdamaian Harus Diapresiasi. Jurnal

Swara Rahima No. 35 Th XI Juli 2011.

Mulia, Siti Musdah, (2007). Muslimah

Reformis: Perempuan Pembaru Agama, Jakarta: Mizan.

Qardhawi, Yusuf. (2004). Islam Radikal: Analisis terhadap Radikalisme dalam Berislam dan Upaya Pemecahannya, terj. Hawin Murtadho, Solo: Era Intermedi.

Turmudzi, Endang (ed.). (2005). Islam dan Radikalisme di Indonesia, Jakarta: LIPI Press.

Wahyuningrum, Sri Lestari. (2007). Perempuan dan Perdamaian di Aceh, dalam Women for Peace.

Zada, Khamami. (2002). Islam Radikal: Pergulatan Ormas-ormas Islam Garis Keras di Indonesia, Bandung: Teraju 